\title{
Comparative Study of Tiapride and Neuroleptics with Anti-Dopamine Activity on Convulsive Seizure in Mice
}

\author{
Hisashi SATOH, Hajime NAKANISHI, Kiyoharu SHIRAKAWA, \\ Yoshiro KOHJIMOTO, Tomoyuki KUWAKI, Takaharu ONO and \\ Fumio SHIBAYAMA \\ Research Laboratories, Fujisawa Pharmaceutical Co., Ltd., \\ 2-1-6 Kashima, Yodogawa-ku, Osaka 532, Japan
}

Accepted September 22, 1986

\begin{abstract}
The effects of tiapride on the convulsive seizures induced by pentylenetetrazole, strychnine, picrotoxin and bemegride, and on electric seizure are reported and compared with those of sulpiride, chlorpromazine, haloperidol and reserpine. The number of deaths and intensity of convulsion increased dosedependently and also with the increase in amplitude of electric shock. Tiapride and a similar compound, sulpiride, did not affect these seizures, whereas chlorpromazine potentiated strychnine-induced and electric seizure. Haloperidol and reserpine potentiated electric seizure, and chlorpromazine and reserpine tended to potentiate bemegride-induced seizure. Reserpine also tended to potentiate pentylenetetrazole-induced seizure. These results suggest that tiapride would be clinically safer than other drugs with anti-dopamine activity, except for sulpiride.
\end{abstract}

Tiapride, $\quad \mathrm{N}$-[2-(diethylamino)ethyl]-5(methylsulfonyl)-o-anisamide, has a chemical structure and binding specificity to dopamine receptor similar to sulpiride, and it has been used to treat elderly patients with organic psychosis (1). Neuroleptics with antidopamine activity are also used in aged patients with organic psychosis, but these drugs occasionally induce seizure (2-4). Because the seizure-inducing potential of tiapride has not been examined, we studied its effect on the convulsion induced by pentylenetetrazole, strychnine, picrotoxin and bemegride as well as on electric seizure, and these effects were compared with those of sulpiride, chlorpromazine, haloperidol and reserpine.

\section{Materials and Methods}

Animals: Female ICR mice aged 6 weeks and weighing 17.2-30.0 g (Shizuoka Agricultural Cooperative Association for Laboratory Animals) were used.

Convulsants-induced seizure: Pentylenetetrazole, strychnine, picrotoxin and beme- gride were used as convulsants. A preliminary experiment was conducted to determine the death-inducing threshold of the four convulsants. Animals were used in groups of 10 to 20 . The number of animals that died within $1 \mathrm{hr}$ after dosing with a convulsant was used to determine the death-inducing threshold of each compound. Each threshold dose of convulsant was given to 10 or 20 animals to examine the effect of the test drugs.

Electric seizure: Each dose of the test drugs was given to 10 animals. Electric current was increased $0.5 \mathrm{~mA}$ per sec. The amplitude of the current (mA) inducing clonic or tonic convulsion was measured, that is, each amplitude was expressed as the threshold of the respective convulsion.

Drugs: The test drugs were tiapride hydrochloride, sulpiride (Delagrange), chlorpromazine hydrochloride (synthesized at our Laboratories), haloperidol (Janssen) and reserpine (Serpasil ${ }^{\mathbb{E}}$ for injection, Takeda). Convulsants used in this study were pentylenetetrazole (Tokyo Kasei), strychnine 
H. Satoh et al.

nitrate (Sigma), picrotoxin (Nakarai) and bemegride (Wako). All drugs except haloperidol and sulpiride were dissolved in saline or distilled water. Haloperidol and sulpiride were dissolved in a minimum amount of $20 \%$ acetic acid and $1 \mathrm{~N}$ sulfuric acid. respectively, and the $\mathrm{pH}$ of the solution was adjusted to 7.0 with $1 \mathrm{~N}$ sodium hydroxide. Reserpine was diluted with distilled water. All the convulsants were given i.p. The test drugs except for reserpine were given p.o. $1 \mathrm{hr}$ before challenge. Reserpine was given i.p. $24 \mathrm{hr}$ before challenge.

Statistics: Statistical significance was calculated by Student's $t$-test or Fisher's exact probability test (5).

\section{Results}

Death-inducing threshold of convulsants: Table 1 shows the death-inducing threshold of each convulsant. All the convulsants caused death dose-dependently. The doseeffect curve of each convulsant was abrupt. The doses of convulsants used to examine the effects of the test drugs were as follows: pentylenetetrazole, 40 and $70 \mathrm{mg} / \mathrm{kg}$ : strychnine, 1.25 and $1.5 \mathrm{mg} / \mathrm{kg}$; picrotoxin. 7 and $9 \mathrm{mg} / \mathrm{kg}$; and bemegride, 20 and 30 $m g / k g$, i.p.

Effect of drugs on death: The effect of the test drugs on pentylenetetrazole-induced seizure is shown in Table 2. Reserpine dosedependently potentiated the death of animals treated with $40 \mathrm{mg} / \mathrm{kg}$ of pentylenetetrazole. The other drugs had no effect.

The effect of the drugs on strychnineinduced seizure is shown in Table 3 . Only chlorpromazine significantly potentiated the death-inducing effect of strychnine.

The effect of the drugs on picrotoxininduced seizure is shown in Table 4 . None of the drugs affected the seizure.

The effect of the drugs on bemegrideinduced seizure is shown in Table 5 . Chlorpromazine and reserpine slightly potentiated the effect of bemegride. The other drugs had no effect.

Effect of drugs on electric seizure: The effect of the test drugs on electric seizure is shown in Table 6 . Chlorpromazine.

Table 1. Death-inducing effect of convulsants

\begin{tabular}{ccc}
\hline Convulsant & $\begin{array}{c}\text { Dose } \\
(\mathrm{mg} / \mathrm{kg}, \mathrm{i.p.})\end{array}$ & $\begin{array}{c}\text { Animals died } \\
\text { Animals used }\end{array}$ \\
\hline & 40 & $0 / 20$ \\
Pentylenetetrazole & 50 & $2 / 20$ \\
& 60 & $1 / 20$ \\
& 70 & $6 / 20$ \\
& 80 & $17 / 20$ \\
\hline Strychnine & 1 & $0 / 20$ \\
& 1.25 & $3 / 20$ \\
& 1.5 & $4 / 10$ \\
& 1.7 & $15 / 20$ \\
& 2 & $20 / 20$ \\
\hline & 4 & $0 / 10$ \\
& 8 & $3 / 20$ \\
& 9 & $3 / 10$ \\
& 10 & $6 / 10$ \\
& 12 & $9 / 10$ \\
& 16 & $10 / 10$ \\
\hline & 20 & $0 / 20$ \\
& 25 & $1 / 20$ \\
& 30 & $5 / 20$ \\
& 40 & $14 / 20$ \\
& 50 & $20 / 20$ \\
\hline
\end{tabular}

Animals were observed for 1 hr after injection. 
Table 2. Effect of drugs on pentylenetetrazole-induced seizure

\begin{tabular}{|c|c|c|c|c|c|c|c|c|c|}
\hline \multirow{3}{*}{$\begin{array}{c}\text { Dose } \\
(\mathrm{mg} / \mathrm{kg} \\
\text { p.o.) }\end{array}$} & \multicolumn{9}{|c|}{ Number of animals died/Number of animals used } \\
\hline & \multicolumn{4}{|c|}{ Pentylenetetrazole $40 \mathrm{mg} / \mathrm{kg}$ (i.p.) } & \multicolumn{5}{|c|}{ Pentylenetetrazole $70 \mathrm{mg} / \mathrm{kg}$ (i.p.) } \\
\hline & Tiapride & Sulpiride & $\begin{array}{l}\text { Chlor- } \\
\text { promazine }\end{array}$ & $\begin{array}{l}\text { Halo- } \\
\text { peridol }\end{array}$ & Tiapride & Sulpiride & $\begin{array}{l}\text { Chlor- } \\
\text { promazine }\end{array}$ & $\begin{array}{l}\text { Halo- } \\
\text { perido! }\end{array}$ & Reserpine \\
\hline 0 & $0 / 10$ & $0 / 10$ & $0 / 10$ & $0 / 10$ & $3 / 10$ & $3 / 10$ & $4 / 10$ & $5 / 10$ & $4 / 10$ \\
\hline 0.32 & - & - & 一 & $0 / 10$ & - & - & - & $3 / 10$ & $4 / 10$ \\
\hline 1 & - & $\ldots$ & $0 / 10$ & $0 / 10$ & - & - & $4 / 10$ & $1 / 10$ & $3 / 10$ \\
\hline 3.2 & $0 / 10$ & $0 / 10$ & $0 / 10$ & $0 / 10$ & $3 / 10$ & $5 / 10$ & $5 / 10$ & $3 / 10$ & $7 / 10$ \\
\hline 10 & $0 / 10$ & $0 / 10$ & $0 / 10$ & $0 / 10$ & $2 / 10$ & $0 / 10$ & $0 / 10$ & $1 / 10$ & $9 / 10$ \\
\hline 32 & $0 / 10$ & $0 / 10$ & $0 / 10$ & $0 / 10$ & $2 / 10$ & $0 / 10$ & $0 / 10$ & $8 / 10$ & \\
\hline 100 & $0 / 10$ & $0 / 10$ & $0 / 10$ & & $1 / 10$ & $3 / 10$ & $5 / 10$ & & \\
\hline 320 & $0 / 10$ & $0 / 10$ & & & $3 / 10$ & $3 / 10$ & & & \\
\hline
\end{tabular}

All drugs except reserpine were given p.o. $1 \mathrm{hr}$ before injection of pentylenetetrazole. Reserpine was given i.p. $24 \mathrm{hr}$ before injection of pentylenetetrazole.

Table 3. Effect of drugs on strychnine-induced seizure

\begin{tabular}{|c|c|c|c|c|c|c|c|c|c|}
\hline \multirow{3}{*}{$\begin{array}{c}\text { Dose } \\
(\mathrm{mg} / \mathrm{kg} \\
\text { p.o.) }\end{array}$} & \multicolumn{9}{|c|}{ Number of animals died/Number of animals used } \\
\hline & \multicolumn{4}{|c|}{ Strychnine $1.25 \mathrm{mg} / \mathrm{kg}$ (i.p.) } & \multicolumn{5}{|c|}{ Strychnine $1.5 \mathrm{mg} / \mathrm{kg}$ (i.p.) } \\
\hline & Tiapride & Sulpiride & $\begin{array}{l}\text { Chlor- } \\
\text { promazine }\end{array}$ & $\begin{array}{l}\text { Halo- } \\
\text { peridol }\end{array}$ & Tiapride & Sulpiride & $\begin{array}{l}\text { Chlor- } \\
\text { promazine }\end{array}$ & $\begin{array}{l}\text { Halo- } \\
\text { peridol }\end{array}$ & Reserpine \\
\hline 0 & $1 / 10$ & $1 / 10$ & $0 / 10$ & $0 / 10$ & $7 / 10$ & $5 / 10$ & $2 / 10$ & $4 / 10$ & $5 / 20$ \\
\hline 0.32 & - & - & - & $0 / 10$ & - & — & - & $1 / 10$ & $0 / 10$ \\
\hline 1 & - & - & $1 / 10$ & $0 / 10$ & $\ldots$ & - & $1 / 10$ & $0 / 10$ & $0 / 10$ \\
\hline 3.2 & $0 / 10$ & $0 / 10$ & $2 / 10$ & $2 / 10$ & $3 / 10$ & $2 / 10$ & $3 / 10$ & $4 / 10$ & $1 / 10$ \\
\hline 10 & $1 / 10$ & $0 / 10$ & $3 / 10$ & $1 / 10$ & $4 / 10$ & $5 / 10$ & $6 / 10$ & $3 / 10$ & $1 / 10$ \\
\hline 32 & $0 / 10$ & $0 / 10$ & $1 / 10$ & $0 / 10$ & $4 / 10$ & $1 / 10$ & $4 / 10$ & $3 / 10$ & \\
\hline 100 & $0 / 10$ & $0 / 10$ & $3 / 10$ & & $3 / 10$ & $1 / 10$ & $9 / 10^{*}$ & & \\
\hline 320 & $3 / 10$ & $0 / 10$ & & & $5 / 10$ & $4 / 10$ & & & \\
\hline
\end{tabular}

All drugs except reserpine were given p.o. 1 hr before injection of strychnine. Reserpine was given i.p. 24 hr before injection of strychnine. * : $P<0.05$

Table 4. Effect of drugs on picrotoxin-induced seizure

\begin{tabular}{|c|c|c|c|c|c|c|c|c|c|}
\hline \multirow{3}{*}{$\begin{array}{c}\text { Dose } \\
(\mathrm{mg} / \mathrm{kg} \\
\text { p.o.) }\end{array}$} & \multicolumn{9}{|c|}{ Number of animals died/Number of animals used } \\
\hline & \multicolumn{4}{|c|}{ Picrotoxin $7 \mathrm{mg} / \mathrm{kg}$ (i.p.) } & \multicolumn{5}{|c|}{ Picrotoxin $9 \mathrm{mg} / \mathrm{kg}$ (i.p.) } \\
\hline & Tiapride & Sulpiride & $\begin{array}{l}\text { Chlor- } \\
\text { promazine }\end{array}$ & $\begin{array}{l}\text { Halo- } \\
\text { peridot }\end{array}$ & Tiapride & Sulpiride & $\begin{array}{l}\text { Chlor- } \\
\text { promazine }\end{array}$ & $\begin{array}{l}\text { Halo- } \\
\text { peridol }\end{array}$ & Reserpine \\
\hline 0 & $0 / 10$ & $0 / 10$ & $4 / 20$ & $0 / 10$ & $2 / 10$ & $6 / 20$ & $8 / 20$ & $8 / 20$ & $3 / 10$ \\
\hline 0.32 & - & - & $\ldots$ & $0 / 10$ & - & - & $\longrightarrow$ & $1 / 10$ & $1 / 10$ \\
\hline 1 & - & - & $1 / 10$ & $0 / 10$ & - & - & $0 / 10$ & $1 / 10$ & $1 / 10$ \\
\hline 3.2 & $0 / 10$ & $0 / 10$ & $0 / 10$ & $1 / 10$ & $2 / 10$ & $0 / 10$ & $2 / 10$ & $0 / 10$ & $4 / 10$ \\
\hline 10 & $0 / 10$ & $0 / 10$ & $0 / 10$ & $0 / 10$ & $1 / 10$ & $2 / 10$ & $3 / 10$ & $1 / 10$ & $2 / 10$ \\
\hline 32 & $0 / 10$ & $0 / 10$ & $0 / 10$ & $0 / 10$ & $2 / 10$ & $4 / 10$ & $4 / 10$ & $3 / 10$ & \\
\hline 100 & $0 / 10$ & $0 / 10$ & $0 / 10$ & & $0 / 10$ & $1 / 10$ & $4 / 10$ & & \\
\hline 320 & $0 / 10$ & $0 / 10$ & & & $3 / 10$ & $3 / 10$ & & & \\
\hline
\end{tabular}

All drugs except reserpine were given p.o. 1 hr before injection of picrotoxin. Reserpine was given i.p. $24 \mathrm{hr}$ before injection of picrotoxin. 
Table 5. Effect of drugs on bemegride-induced seizure

\begin{tabular}{|c|c|c|c|c|c|c|c|c|c|}
\hline \multirow{3}{*}{$\begin{array}{r}\text { Dose } \\
(\mathrm{mg} / \mathrm{kg} \\
\text { p.o.) }\end{array}$} & \multicolumn{9}{|c|}{ Number of animals died/Number of animals used } \\
\hline & \multicolumn{4}{|c|}{ Bemegride $20 \mathrm{mg} / \mathrm{kg}$ (i.p.) } & \multicolumn{5}{|c|}{ Bemegride $30 \mathrm{mg} / \mathrm{kg}$ (i.p.) } \\
\hline & Tiapride & Sulpiride & $\begin{array}{l}\text { Chlor- } \\
\text { promazine }\end{array}$ & $\begin{array}{l}\text { Haio- } \\
\text { peridol }\end{array}$ & Tiapride & Sulpiride & $\begin{array}{l}\text { Chlor- } \\
\text { promazine }\end{array}$ & $\begin{array}{l}\text { Halo-- } \\
\text { peridol }\end{array}$ & Reserpine \\
\hline 0 & $0 / 20$ & $0 / 10$ & $0 / 10$ & $0 / 10$ & $3 / 10$ & $10 / 20$ & $3 / 10$ & $4 / 10$ & $5 / 20$ \\
\hline 0.32 & - & - & - & $0 / 10$ & - & - & - & $2 / 10$ & $2 / 10$ \\
\hline 1 & - & - & $0 / 10$ & $0 / 10$ & - & - & $6 / 10$ & $2 / 10$ & $3 / 10$ \\
\hline 3.2 & $0 / 10$ & $0 / 10$ & $0 / 10$ & $0 / 10$ & $3 / 10$ & $6 / 10$ & $6 / 10$ & $5 / 10$ & $6 / 10$ \\
\hline 10 & $0 / 10$ & $0 / 10$ & $0 / 10$ & $0 / 10$ & $1 / 10$ & $5 / 10$ & $8 / 10$ & $2 / 10$ & $6 / 10$ \\
\hline 32 & $0 / 10$ & $0 / 10$ & $0 / 10$ & $1 / 10$ & $2 / 10$ & $8 / 10$ & $7 / 10$ & $5 / 10$ & \\
\hline 100 & $0 / 10$ & $0 / 10$ & $1 / 10$ & & $5 / 10$ & $5 / 10$ & $2 / 10$ & & \\
\hline 320 & $0 / 10$ & $0 / 10$ & & & $1 / 10$ & $4 / 10$ & & & \\
\hline
\end{tabular}

All drugs except reserpine were given p.o. 1 hr before injection of bemergride. Reserpine was given i.p. $24 \mathrm{hr}$ before injection of bemegride.

Table 6. Effect of drugs on electric seizure

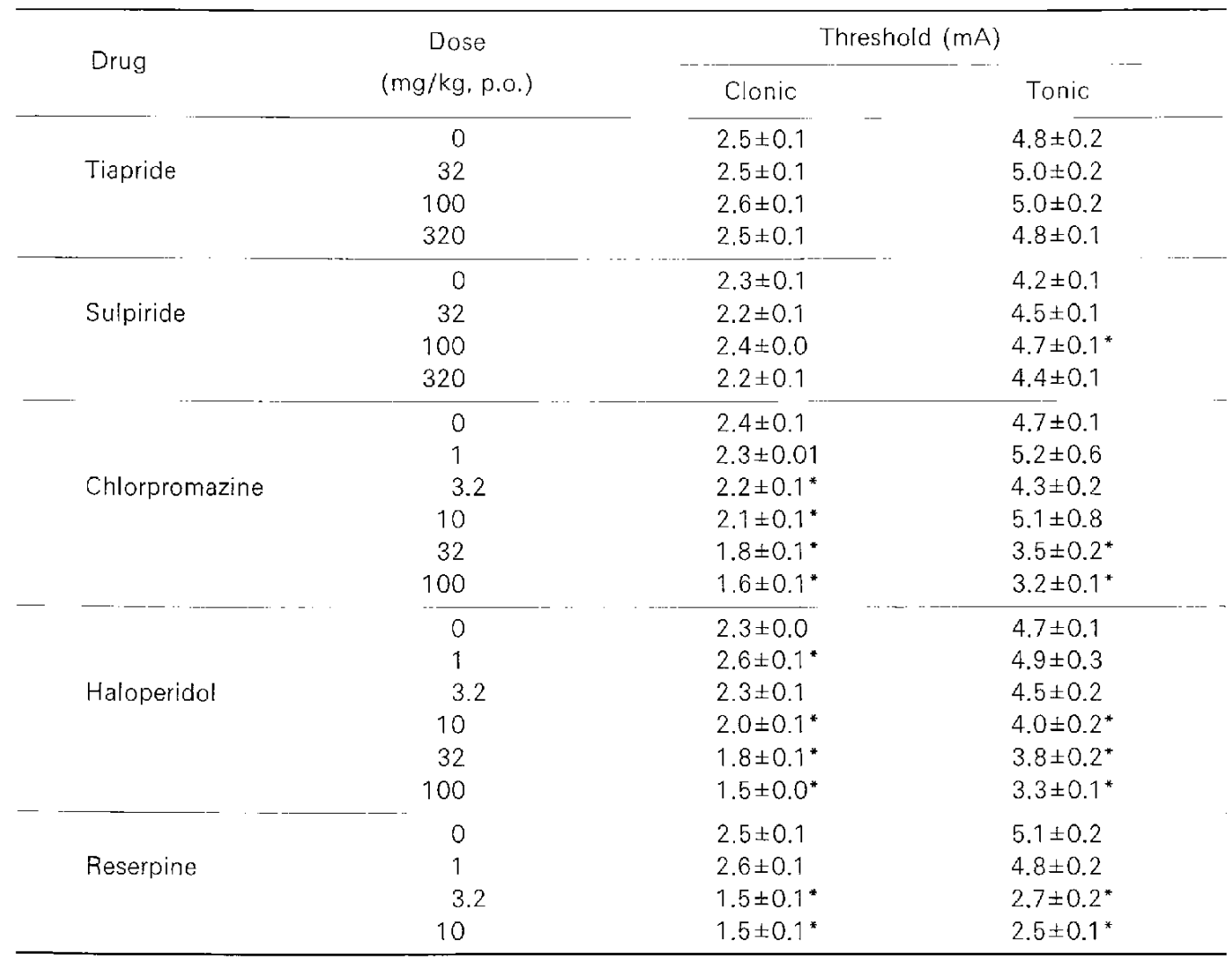

All drugs except reserpine were given p.o. $1 \mathrm{hr}$ before electric stimulation. Reserpine was given i.p. $24 \mathrm{hr}$ before electric stimulation. Figures show the mean \pm S.E. ${ }^{*}: P<0.05$

haloperidol and reserpine potentiated the electric seizure, that is, these drugs lowered the amplitude inducing clonic and tonic convulsion. Tiapride and sulpiride had no effect.

The effects of the test drugs on seizure are 
Table 7. Summary of the effect of drugs on convulsant-induced and electric seizures

\begin{tabular}{|c|c|c|c|c|c|c|}
\hline \multirow[t]{2}{*}{ Seizure } & \multirow{2}{*}{$\begin{array}{l}\text { Pentylene- } \\
\text { tetrazol }\end{array}$} & \multirow{2}{*}{ Strychnine } & \multirow{2}{*}{ Picrotoxin } & \multirow{2}{*}{ Bemegride } & \multicolumn{2}{|c|}{ Electric } \\
\hline & & & & & Clonic & Tonic \\
\hline Tiapride & $\rightarrow$ & $\rightarrow$ & $\rightarrow$ & $\rightarrow$ & $\rightarrow$ & $\rightarrow$ \\
\hline Sulpiride & $\rightarrow$ & $\rightarrow$ & $\rightarrow$ & $\rightarrow$ & $\rightarrow$ & $\rightarrow$ \\
\hline Chlorpromazine & $\rightarrow$ & $\uparrow$ & $\rightarrow$ & $\nearrow$ & $\uparrow$ & $\uparrow$ \\
\hline Haloperidol & $\rightarrow$ & $\rightarrow$ & $\rightarrow$ & $\rightarrow$ & $\uparrow$ & $\uparrow$ \\
\hline Reserpine & $\not$ & $\rightarrow$ & $\rightarrow$ & $\not$ & $\uparrow$ & $\uparrow$ \\
\hline
\end{tabular}

$\rightarrow$ : No effect. $\uparrow$ : Potentiation. $\not$ : Slight potentiation.

summarized in Table 7. Tiapride, like sulpiride, had no effect on any of these seizures, whereas chlorpromazine potentiated strychnine-induced and electric seizures. Haloperidol and reserpine also potentiated electric seizure, and chlorpromazine and reserpine slightly potentiated bemegrideinduced seizure. Reserpine also slightly potentiated pentylenetetrazole-induced seizure.

\section{Discussion}

Reserpine, an amine depleter, lowers the seizure threshold in rodents (6). Clinically. neuroleptics with anti-dopamine activity occasionally induce convulsive seizure (2-4). and reserpine weakens the effect of anticonvulsants (7). Tiapride is a dopamine specific antagonist in the central nervous system (8). However, its effect on the seizure threshold has not been examined. In our experiments, tiapride had no effect on the seizure induced by any of the convulsants or on electric seizure.

Sulpiride, like tiapride, was also without effect, but haloperidol, chlorpromazine and reserpine potentiated or tended to potentiate the seizure in some experiments.

The mechanisms of the convulsants are not clear: however, amine neurons and some other neurons are supposed to be involved in drug-induced and electric seizures. Norepinephrine $(9,10)$, serotonin $(9,11,12)$, GABA (13), acetylcholine (14) and adenosine (9) are supposed to be involved in pentylenetetrazole-induced convulsion. Glycine $(15,16)$ and GABA (17. 18) are involved in strychnine and picrotoxininduced convulsions, respectively. GABA and an unknown substance are reported to be involved in bemegride-induced convulsion (19). In electric seizure, such substances as norepinephrine, serotonin and adenosine are supposed to participate (9). In contrast, dopamine has little effect on pentylenetetrazole-induced and electric seizures (9).

Such neuroleptics as chlorpromazine block many amine receptors as well as the dopamine receptor $(20,21)$. and reserpine lowers the activity of norepinephrine, serotonin and dopamine on the receptor sites. Therefore, these drugs would potentiate the seizure, and this effect might correlate with the seizureinducing effect in clinical use. In contrast, tiapride and sulpiride act only on the dopamine receptor (8). Therefore, the absence of an effect on scizure may be due to their selective blocking activity on the dopamine receptor. Sulpiride only poorly penetrates the blood-brain barrier (22). and further experiments are needed to confirm its effect on seizure in the case of intraventricular injection. However, the drug is safe for even schizophrenics with epileptic syndrome (23).

In conclusion, tiapride would be clinically safer than other anti-dopamine drugs except for sulpiride.

\section{References}

1 Shimizu, M., Hasegawa, K., Nishimura, T., Miyasaka, M., Ishino, $H$. and Yamada, M.: Comparison of clinical effects of tiapride, sulpiride and chlorpromazine in the elderly patients with organic psychosis using multicenter double blind technique. Japan. J. Clin. Psychiatry 13, 1017-1031 (1984) 
2 Logothetics, J.: Spontaneous epileptic seizures and electro-encepharographic changes in the course of phenothiazine therapy. Neurology 17. 869-877 (1967)

3 Lomas, J., Boardman, B.H. and Markowe, M.: Complications of chlorpromazine therapy in 800 mental-hospital patients. Lancet 1, 1144 (1955)

4 Spats, R., Lorenzi, E., Kugler, J. und Ruther, E.: Häufigkeite und Form von EEG-Anomalien bei Clozapintherapy. Arzneimittelforsch. 28, 14991500 (1978)

5 Siegel, S.: Non-parametric Statistics for the Behavioral Sciences. p. 96-104. McGraw-Hill Book, Co., Inc., New York (1956)

6 Buterbaugh, G.G. and London, E.D.: The relationship between magnitude of electroshock stimulation and the effects of digitoxigenin, pentylenetetrazole and brain monoamine reduction on electroshock convulsive thresholds. Neuropharmacology 16, 617-623 (1977)

7 Arushanyan, E.B.: Central monoaminergic mechanisms and generalized convulsions. Zh. Nervopatol. Psikhiatr. 76, 453-463 (1976)

8 Chivers, J.K., Gommeren, W., Jenner, P., Leysen, J.r Marsden, C.D.r Reavill, C. and Theodorou, A.: Comparison of in vivo and in vitro actions of tiapride in rodents. Br. J. Pharmacol. 78, Supp. 398P (1983)

9 Burley, E.S. and Ferrendelli, J.A.: Regulatory effects of neurotransmitters on electroshock and pentylenetetrazole seizures. Fed. Proc. 43, $2521-$ 2524 (1984)

10 Kilian, M. and Frey, H.-H.: Central monoamines and convulsive thresholds in mice and rats. Neuropharmacology 12, 681-692 (1973)

11 De La Torre, J.C. and Mullan, S.: A possible-role for 5-hydroxy-tryptamine in drug-induced seizures. J. Pharm. Pharmacol. 22, 858-859 (1970)

12 Lessin, A.W. and Parkes, M.W.: The effects of reserpine and other agents upon leptazole convulsions in mice. Br. J. Pharmacol. 14, 108-111 (1950)

13 MacDonald, R.L. and Barker, J.L.: Pentylenetetrazole and penicillin are selective antagonists of GABA-mediated post-synaptic inhibition in cultures mammalian neurons. Nature 267, $720-$ $721(1977)$
14 Rastogi, S.K., Puri, J.N., Sinha, J.N. and Bhargava, K.P.: Involvement of central cholinoceptors in metrazole-induced convulsions. Psychopharmacology (Berlin) 65, 215-217 (1979)

15 Muller, W.E. and Snyder, S.H.: Strychnine binding associated with synaptic glycine receptors in rat spinal cord membranes: Ionic influences. Brain Res. 147, 107-116 (1978)

16 Young, A.B. and Snyder, S.H.: Strychnine binding in rat spinal cord membranes associated with the synaptic glycine receptor: Comparativity of glycine interactions. Mol. Pharmacol. 10, 790-809 (1974)

17 Schlosser, W. and Franco, S.: Modification of GABA-mediated depolarization of the cat ganglion by pentobarbital and two benzodiazepines. Neuropharmacology 18, 377-381 (1979)

18 Ticku, M.K., Van Ness, P.C., Haycock, J.W., Levy, W.B. and Olsen, R.W.: Dihydropicrotoxinin binding sites in rat brain: Comparison to GABA receptors. Brain Res. 150, 642-647 (1978)

19 Soubrie, P. and Simon, P.: Comparative study of the antagonism of bemegride and picrotoxin of behavioural depressant effects of diazepam in rats and mice. Neuropharmacology 17, 121-125 (1978)

20 Closse, A., Frick, W., Dravid, A., Bolliger, G., Hauser, D., Sauter, A. and Touber, H.-J.: Classification of drugs according to receptor binding profiles. Naunyn Schmiedebergs Arch. Pharmacol. 327, 95-101 (1984)

21 Ortmann, R., Bischoff, S., Radeke, E., Buech, O. and Delini-Stular, A.: Correlations between different measures of antiserotonin activity of drugs: Study with neuroleptics and serotonin receptor blockers. Naunyn Schmiedebergs Arch. Pharmacol. 321, 265-270 (1982)

22 Honda, F., Satoh, Y., Shimomura, K., Satoh, H., Noguchi, H., Uchida, S. and Kato, R.: Dopamine receptor blocking activity of sulpiride in the central nervous system. Japan. J. Pharmacol. 27, 394-411 (1977)

23 Hara, T., Nogami, S., Inada, O., Kitamura, T. and Kawai, Y.: Clinical effect of sulpiride in psychiatryinjection, tablet and powder. Medical Consultation and New Remedies 13, 451-461 (1976) (in Japanese) 